Document downloaded from:

http://hdl.handle.net/10251/81266

This paper must be cited as:

Gómez, F.; Igual Ramo, M.; Pagán Moreno, MJ.; Camacho Vidal, MM. (2013). Changes in the microbiological and physicochemical quality during storage of osmotically dehydrated strawberry jam stabilized with plant extracts. CyTA - Journal of Food. 11(3):248-255. doi:10.1080/19476337.2012.730553.

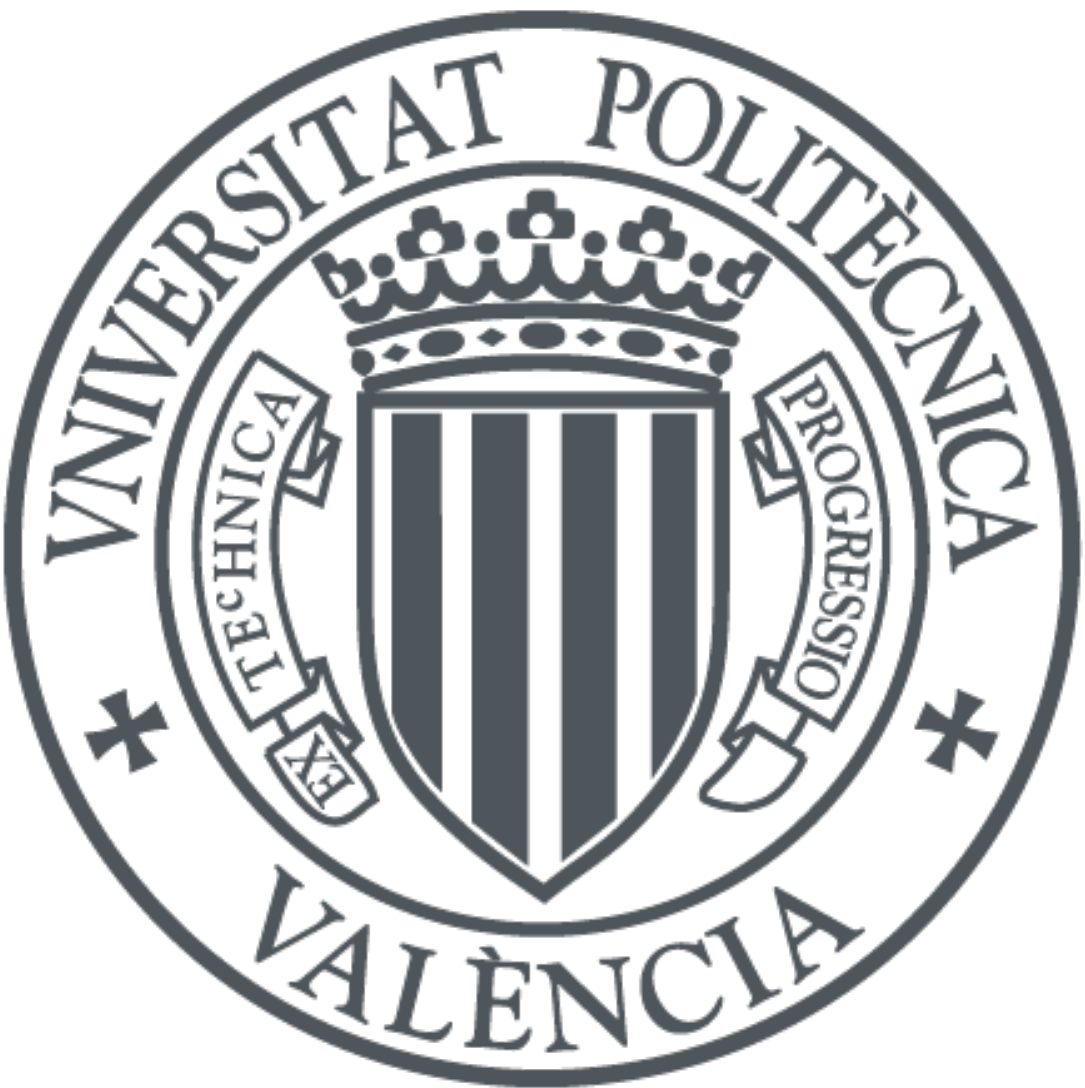

The final publication is available at

http://doi.org/ 10.1080/19476337.2012.730553

Copyright Taylor \& Francis

Additional Information 


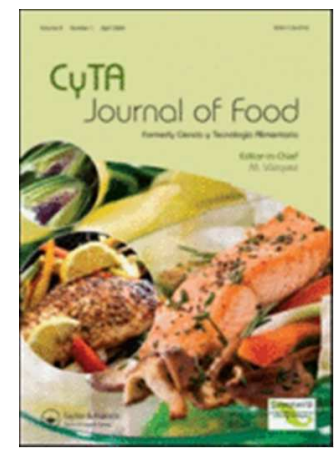

\section{Changes in the microbiological and physicochemical quality during storage of osmotically dehydrated strawberry jam stabilized with plant extracts}

\begin{tabular}{|r|l|}
\hline Journal: & CYTA - Journal of Food \\
\hline Manuscript ID: & TCYT-2012-0060.R2 \\
\hline Manuscript Type: & Food Science and Technology \\
\hline Date Submitted by the Author: & n/a \\
\hline Complete List of Authors: & $\begin{array}{l}\text { Gómez, Fabiola; Universitat Politècnica de Valencia, } \\
\text { Igual, Marta; Universitat Politècnica de Valencia, } \\
\text { María Jesús, Pagán; Universitat Politècnica de Valencia, } \\
\text { Camacho, María del Mar; Universitat Politècnica de València, Tecnología de } \\
\text { Alimentos }\end{array}$ \\
\hline Keywords: & strawberry jam, osmotic dehydration, plant extract, microbiology, storage \\
\hline &
\end{tabular}


Changes in the microbiological and physicochemical quality during storage of osmotically dehydrated strawberry jam stabilized with plant extracts

Cambios en la calidad microbiológica y fisicoquímica durante el almacenamiento de mermelada de fresa deshidratada osmóticamente estabilizada con extractos vegetales

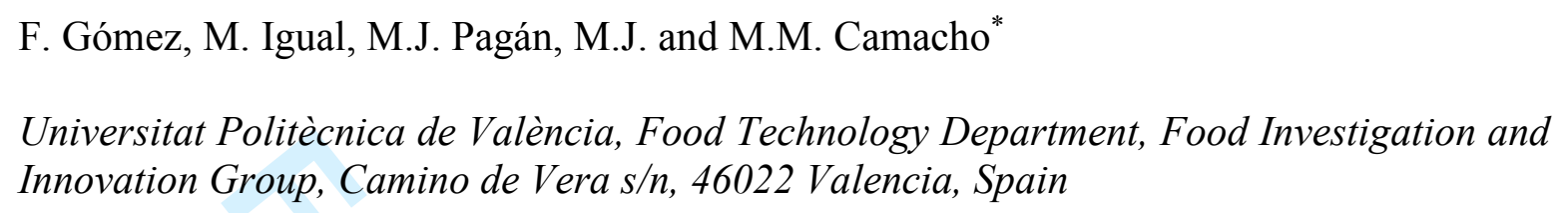

\footnotetext{
* Corresponding author: Tel.: 963879 831. E-mail address:mdmcamvi@tal.upv.es (Camacho, M.M).
} 
Abstract

\title{
Resumen
} balsamic lemon) added in the elaboration of jam obtained from osmotically dehydrated strawberry were studied. Lemon extract exhibited the highest antifungal activity against the microbiota present. Subsequently, the effect of the addition of a combination of lemon extract, as antifungal, and pomegranate, as antimicrobial, on the microbiological and physico-chemical properties of this jam were evaluated through storage. The use of plant extracts reduces the microbial charge (aerobic mesophylls, lactic acid bacteria and moulds and yeasts) and is most effective when pomegranate and lemon extracts are used, as these do not cause significant changes in the physicochemical characteristics. Furthermore, adding pomegranate and/or lemon extract improved the consistency of jams during storage. In general, the addition of extracts involved an increase in stability of strawberry jam during storage at room temperature.

\begin{abstract}
Se han estudiado las propiedades antifúngicas de algunos extractos de plantas (granada, romero, limón y limón balsámico) para su aplicación en la elaboración de mermelada obtenida con fresa osmóticamente deshidratada. El extracto de limón presentó la mayor actividad antifúngica frente a la microbiota presente. Posteriormente, se han evaluado los efectos sobre las propiedades microbiológicas y físico-químicas de esta mermelada, durante el almacenamiento, de la adición de una combinación de extractos de limón como antifúngico y granada como antimicrobiano.La utilización de extractos vegetales reduce la carga microbiana (mesófilos aerobios, bacterias ácido lácticas y mohos y levaduras) y es más efectiva cuando se utilizan los extractos de granada y limón, ya que no provocan cambios significativos en las características físico-químicas. Por otra parte, la adición de granada y / o extracto de limón mejora la consistencia de las mermeladas durante el almacenamiento. En general, la adición de extractos implica un aumento en la estabilidad de la mermelada de fresa durante el almacenamiento a temperatura ambiente.
\end{abstract}

Keywords: strawberry jam, osmotic dehydration, plant extract, microbiology.

\section{Introduction}

The jam industry needs to improve its competitiveness as a consequence of the changes that have taken place in consumption habits and the appearance of alternative breakfast products on the market (Grigelmo-Miguel \& Martín-Belloso, 1999). An attractive red colour is one of the most important characteristics of strawberry jam, as consumers are attracted to the typical aroma and the bright red colour (Goessinger, Mayer, Radocha, Hoefler, Boner, Groll, Bauer, \& Berghofer, E., 2009). The colour stability of red fruit products is affected by temperature, $\mathrm{pH}$, oxygen, sugar content, ascorbic acid and metals, which affect the pigments (Withy, Nguyen, Wrolstad \& Heatherbell, 1993). Anthocyanins are the main pigments accounting for the characteristic red color. (Viguera, Zafrilla, \& Barberan, 1997,). Other important parameters are the typical sweet-sour strawberry flavour and the appropriate consistency. The cultivar selected and its degree or ripeness is major factors in determining the taste and colour of strawberry jams (Sundfǿr, 2001; Redalen \& Haffner, 
2002). Pigment degradation results in discolouration of the product. During processing the pigments can be hydrolysed and degraded to anthocyanidin and sugar. Anthocyanidins are unstable when exposed to light and are more easily oxidized than anthocyanins, and consequently more susceptible to turn brown (Herrmann, 1972). Browning and discoloration during storage of strawberry jams are common problems (García-Viguera, Zafrilla, \& Tomás-Barberán, 1999).

Fruit are a source of nutrients and antioxidant compounds. A common way to consume fruit is through jam. However, the beneficial fruit properties are lost due to the high temperatures and long process times involved in jam making. Osmotic dehydration could offer an alternative to the conventional jam-making process, since this technique uses lower temperatures $\left(30-40^{\circ} \mathrm{C}\right)$ that are less aggressive against labile compounds in the fruit (Shi, Chiralt, Fito, Serra, Escoin \& Gasque, 1996; García-Martínez, Ruiz-Diaz, MartínezMonzó, Camacho, Martínez-Navarrete \& Chiralt, 2002; Igual, Contreras \& MartínezNavarrete, 2010). Nevertheless, this technique does not destroy some types of bacteria, moulds and yeasts, and there are osmophilic fungal species that can live in high sugar concentrations (Pascual \& Calderón, 2000). A possible solution to this problem could be the use of plant extracts such as pomegranate, lemon, balsamic lemon and rosemary. Pomegranate (Punica granatum L) is a very rich source of anthocyanins, ellagitannins and other phenolic compounds with proven antioxidant activity (Madrigal-Carballo, Rodriguez, Krueger, Dreher, \& Reed, 2009) and antimicrobial effects (Voravuthikunchai, Lortheeranuwat, \& Jeeju, 2004). Pomegranate is effective against Aspergillus flavus (Krishnamurthy \& Shashikala, 2006). Lemon (Citrus limon) has antimicrobial and antifungal activity (Viuda-Martos, Ruiz-Navajas, Fernandez-Lopez \& Perez-Alvarez, 2008) and antioxidant activity (Xu, Liu, Chen, Ye, Ma, \& Shi, 2008). The antifungal activity is due to the presence of compoundssuch as D-limonene, linalool or citral (Tepe, Akpulat, Sokmen, Daferera, Yumrutas, \& Aydin, 2006; Veldhuizen, Tjeerdsma-Van Bokhoven, Zweijtzer, Burt, \& Haagsman, 2006). Rosemary (Rosmarinus officinalis) slows down the growth of some bacteria and also acts as an antioxidant due to rosamarinic acid, carnosic acid and its phenolic dipteran carnosol, rosmanol y rosmaridiphenol (Pérez-Fons, Garzon, \& Micol, 2010; Yesil-Celiktas, Sevimli, Bedir, \& Vardar-Sukan, 2010).

The objective of this work was to study the antifungal activity in osmotically dehydrated strawberry jam of plant extracts (pomegranate, rosemary, lemon and balsamic lemon) and toevaluate the effect of selected plant extracts on microbiological and physicochemical properties of jam during storage.

\section{Materials and methods}

\section{Raw materials}

"Reina de los Valles" wild strawberry fruit (Fragaria vesca L.) were purchased from a local supermarket. The mean values (and standard deviation) of $\mathrm{a}_{\mathrm{w}},{ }^{\circ} \mathrm{Brix}$ and $\mathrm{pH}$ of strawberry used were 0.980 (0.003), $12.6(0.1)$ and 3.53 (0.01), respectively. An osmotic solution (OS) was prepared by mixing an amount of commercial food grade sucrose with distilled water until it was completely dissolved, thus forming a $65^{\circ}$ Brix syrup. Citrus peel pectin $(60 \%$ degree of esterification, Fluka Biochemika, Switzerland) was added to the jam as gelling agent. Lemon, pomegranate, balsamic lemon and rosemary extract (Nutracitrus, Spain) were used for the antifungal study. 
108 Strawberries placed in the OS (ratio OS:fruit 5:1) were heated to $30{ }^{\circ} \mathrm{C}$ (water bath P-

109 Selecta Precisterm, Barcelona, Spain) with continuous stirring (200 rpm, Heidolph

110 Instruments, RZR 2020, Schwabach, Germany) for $3 \mathrm{~h}$, reaching $\approx 20^{\circ}$ Brix. Osmo111 dehydrated samples were then ground together with part of the OS to obtain jam with $500 \mathrm{~g}$ 112 fresh fruit $/ \mathrm{kg} \mathrm{jam}$, with pectin $(10 \mathrm{~g} / \mathrm{kg} \mathrm{jam})$ as gelling agent, both with and without natural 113 extracts. The jams thus obtained were placed in glass jars and stored at room temperature 114 for $24 \mathrm{~h}$ till analysis and then stored at $25^{\circ} \mathrm{C}$ in darkness for 24 days.

\section{Antifungal activity (in vitro) of extracts}

Two types of microbiological analyses were carried out to obtain the minimal concentration of antifungal activity of the natural extracts: The first method was by agar diffusion in which the natural extract was applied to an agar plate: Chloramphenicol glucose agar (CGA) for moulds and yeasts. $1 \mathrm{~mL}$ of inoculum $\left(10^{8} \mathrm{cfu} / \mathrm{mL}\right.$ for moulds and yeasts) was mixed with the agar on the plate. When the agar solidified, five wells were made and 100 $\mu \mathrm{L}$ of different concentrations of natural extracts were placed in each one. The plates were incubated at $25^{\circ} \mathrm{C}$ for 5 days, during which the extracts diffused through the agar, setting up a concentration gradient. The concentration was inversely proportional to the distance from the well. Inhibition, which is the measure of activity, is indicated by a no-growth zone around the well (Barry, 1986). The results of this test are qualitative, so that microorganisms are generally termed susceptible, intermediate or resistant, according to the diameter of the inhibitory zone (Davidson \& Parish, 1989). The second analytical method was by broth dilution in which the compounds under study were serially diluted and distributed in a nutrient broth (Davidson \& Parish, 1989). A broth containing a mixture of $200 \mathrm{~g} / \mathrm{kg}$ glucose, $100 \mathrm{~g} / \mathrm{kg}$ yeast extract and $200 \mathrm{~g} / \mathrm{kg}$ tryptone (GYT) was used. Natural extracts were applied to these media in the form of an inoculum of altered jam in tubes $\left(10^{8}\right.$ $\mathrm{cfu} / \mathrm{mL})\left(1: 9\right.$ inoculum:nutrient broth ratio), which were incubated at $37^{\circ} \mathrm{C}$ for $24-48 \mathrm{~h} .1$ $\mathrm{mL}$ of the content of each tube was then placed on a CGA plate and incubated in the same way as described above.

The minimum inhibitory concentration (MIC) is defined as the minimum level of natural extract concentration that produces a $90 \%$ reduction in the growth (population) of microbial colonies (Ponce, Fritz, Valle, \& Roura, 2003) or a complete inhibition of visible growth (Jia, Ji, Xing, Zhang, Zhu, \& Wang, 2010). The minimum fungicidal concentration (MFC) is defined as the minimum level of natural extract concentration that produces at least a $99.9 \%$ reduction in the growth of fungal colonies (Ernst, 2005).

\section{Microbiological and physicochemical properties of stored jams}

The evolution of microbiota and physicochemical properties, colour and consistency of jams with the selected extracts were analyzed throughout the 24 -day storage period at $25^{\circ} \mathrm{C}$. Previous studies on plant extracts (Gómez et al., 2012), shown that pomegranate extract was very effective as natural antimicrobial and selected $0.001 \mathrm{~g} / \mathrm{mL}$ as better dose. So, jams without extract, with antimicrobial extract and with antimicrobial and antifungal extract were characterized physicochemically and microbiologically and colour and consistency were also observed throughout 24 days of storage at $25^{\circ} \mathrm{C}$.

Microbiological characterization was based on the following parameters: aerobic mesophylls (ISO, 4833, 2003), lactic acid bacterias (ISO 15214, 1998), coliforms (ISO 
4832: 2006), moulds and yeasts (ISO 21527:2008). Moisture content $\left(\mathrm{x}_{\mathrm{w}}\right)$, ${ }^{\circ} \mathrm{Brix}, \mathrm{pH}$ and water activity $\left(a_{w}\right)$ were determined for all of the formulated jams. $x_{w}$ was determined by drying the sample to constant weight at $60{ }^{\circ} \mathrm{C}$ in a vacuum oven (AOAC method 934.06, 2000). ${ }^{\circ}$ Brix was measured in previously homogenized samples with a refractometer at 20 ${ }^{\circ} \mathrm{C}$ (Zeiss, ATAGO model NAR-3T refractometer, Japan). A dew point hygrometer (FA-st Lab, GBX, France) was used to measure $\mathrm{a}_{\mathrm{w}}$. $\mathrm{pH}$ was measured by means of a CRISON pHmeter. Each analysis was carried out in triplicate.

Jam colour was analysed by a reflection spectrum (Minolta, CM 3600D, Tokyo, Japan) calibrated with a standard white reflective plate. CIE-L*a*b* uniform colour space, $10^{\circ}$ observer and D65 illuminant were selected to calculate colour coordinates. Colour data are provided as CIE- $\mathrm{L}^{*} \mathrm{a} * \mathrm{~b}^{*}$ coordinates, which define colour in a three-dimensional space. $\mathrm{L}^{*}$ indicates lightness, $a^{*}$ indicates chromaticity on a green $(-)$ to red $(+)$ axis and $b^{*}$ chromaticity on a blue (-) to yellow (+) axis. The colour coordinates were then used to calculate hue angle $\left(\mathrm{h}_{\mathrm{ab}}{ }^{*}=\arctan \frac{\mathrm{b}^{*}}{\mathrm{a}^{*}}\right)$, chrome $\left(\mathrm{C}_{\mathrm{ab}}{ }^{*}=\sqrt{\mathrm{a}^{* 2}+\mathrm{b}^{* 2}}\right)$ and colour differences $\left(\Delta \mathrm{E}=\sqrt{\Delta \mathrm{L}^{* 2}+\Delta \mathrm{a}^{* 2}+\Delta \mathrm{b}^{*^{2}}}\right)$ with respect to the strawberry control jam sample. The flow distance of the product was measured with a Bostwick consistometer. This instrument has two compartments, one measures $5 \times 5 \times 3.8 \mathrm{~cm}$ and is separated from the second by a spring-loaded gate. The second compartment measures $5 \times 24 \times 2.5 \mathrm{~cm}$ and its floor has a series of parallel lines drawn across it at $0.5 \mathrm{~cm}$ intervals from the gate to the far end. The controlled weight sample is placed in the first compartment and when the gate is opened the flowing distance after $30 \mathrm{~s}$ is measured (Bourne, 1982). So, the parameter used to characterize the consistency of the samples is the distance that the jam flows across the plate in $30 \mathrm{~s}$ in relation to the weight of the sample $(\mathrm{mm} / \mathrm{g})$.

\section{Statistical analysis}

Analysis of variance (ANOVA) with a confidence level of $95 \%(\mathrm{p}<0.05)$ was applied using Statgraphics Plus 5.1 Software (Statistical Graphics Corporation, USA) to evaluate the differences among samples and the different trend of samples during storage. Principal Component Analysis (PCA) was applied to the correlation matrix of the average values of colour parameters, using the SPSS version 16.0 program.

\section{Results and discussion}

\section{Antifungal activity}

Agar diffusion method showed that at the doses considered (1, 0.5 and $0.34 \mathrm{~g} / \mathrm{mL}$ ) only lemon extract had an antifungal action. In order to quantify this action with greater precision, the broth dilution technique was then used (Davison \& Parish, 1989). The initial jam charge pattern at 24 hours was $1.03 \times 10^{2} \mathrm{cfu} / \mathrm{mL}$ and MIC was 0.2 or $0.1 \mathrm{~g} / \mathrm{mL}$, as defined by Jia et al. (2010) and Ponce et al. (2003), respectively. . Moreover,MFC was 0.1 $\mathrm{g} / \mathrm{mL}$. Therefore, the dose chosen for the lemon extract was $0.1 \mathrm{~g} / \mathrm{mL}$

\section{Effect of pomegranate and lemon extract addition on physicochemical and microbiological parameters}


After dehydration, the fruit reached $20.7 \pm 0.1^{\circ}$ Brix and $60^{\circ}$ Brix osmotic solution.

198

199

200

201

202

203

204

205

206

207

208

209

210

211

212

213

214

215

216

217

218

219

220

221

222

223

224

225

226

227

228

229

230

231

232

233

234

235

236

237

238

239

240

241
In other studies (García-Martínez et al., 2002, Shi et al., 1996, and Igual et al., 2010) using slices of osmotically dehydrated fruit, ${ }^{\circ} \mathrm{Brix}$ had similar values (26 for kiwi, 23 for orange, 20 for strawberry and 30 for grapefruit).

Table 1 shows the ${ }^{\circ}$ Brix, $\mathrm{a}_{\mathrm{w}}$ and $\mathrm{x}_{\mathrm{w}}, \mathrm{pH}$ values and the flow distance corrected for sample weight of the three jam batches: control with no extracts (OD), OD jam with $0.001 \mathrm{~g} / \mathrm{mL}$ of pomegranate extract (OD+PG) and OD jam with $0.001 \mathrm{~g} / \mathrm{mL}$ pomegranate extract and 0,1 $\mathrm{g} / \mathrm{mL}$ lemon extract added by spraying $(\mathrm{OD}+\mathrm{PG}+\mathrm{L})$.

There were no significant differences for $x_{w}$ and $p H$. The $a_{w}$ of OD+PG was significantly lower than $\mathrm{OD}$ and $\mathrm{OD}+\mathrm{PG}+\mathrm{L}$ jams, and consequently had a high ${ }^{\circ} \mathrm{Brix}$ value. The OD sample showed the lowest consistency (highest distance advanced). However, the sample containing both extracts had significantly $(p<0.05)$ higher consistency than OD. This agrees with similar studies by other authors (García-Martínez et al., 2002; Igual et al., 2010) who obtained similar consistency values for jams containing osmotically dehydrated fruit.

The colour coordinates $\left(\mathrm{L}^{*}, \mathrm{a}^{*}\right.$ and $\left.\mathrm{b}^{*}\right), \mathrm{h}^{*}{ }_{\mathrm{ab}}$ and $\mathrm{C}^{*}{ }_{\mathrm{ab}}$ of jams appear in Table 2. The colour differences $(\Delta \mathrm{E})$ of jam with extracts in relation with control jam appear also in this table. OD jam showed significantly $(p<0.05)$ higher values in $L^{*}$ than jams with extracts, however, the $\mathrm{L}^{*}$ value of $\mathrm{OD}+\mathrm{PG}+\mathrm{L}$ was significantly lower $(\mathrm{p}<0.05)$ than OD. The $\mathrm{h}^{*}{ }_{\mathrm{ab}}$ of OD+PG was significantly lower $(\mathrm{p}<0.05)$ than the control. Although the values of $\Delta \mathrm{E}$ with respect to control were small, $\mathrm{OD}+\mathrm{PG}+\mathrm{L}$ showed a colour difference significantly greater than OD+PG. Other references (Gómez et al., 2012) show the results of jam obtained from var. Camarosa strawberries, in which the $\mathrm{L}^{*}$ var. Camarosa jam values were lower than those obtained in this study. However the values of $\mathrm{a}^{*}, \mathrm{~b}^{*}, \mathrm{~h}^{*}{ }_{\mathrm{ab}}$ and $\mathrm{C}^{*}{ }_{\mathrm{ab}}$ were lower in the case of jams made from Fragaria vesca than var. Camarosa. It can therefore be said that the final colour owes more to the variety of strawberry than to the extracts added.

Table 3 shows the counts of aerobic mesophylls, lactic acid bacteria, moulds and yeasts and coliforms for the three batches immediately after processing. There was no coliform development in any of the jams. In general, the initial OD charge was significantly higher $(\mathrm{p}<0.05)$ than the others.

\section{Effect of storage on physicochemical and microbiological parameters}

Figure 1 shows the evolution of $\mathrm{x}_{\mathrm{w}},{ }^{\circ} \mathrm{Brix}, \mathrm{a}_{\mathrm{w}}$ and $\mathrm{pH}$ for the three jams stored at room temperature $\left(25{ }^{\circ} \mathrm{C}\right)$ for 24 days. The control of these parameters is very important since they are indicators of the stability of the product. Any physicochemical changes indicate alterations and/or deterioration during storage and affect their shelf life. In general, the jams studied showed similar behavior during storage in terms of $\mathrm{x}_{\mathrm{w}}, \mathrm{a}_{\mathrm{w}}$ and $\mathrm{pH}$. However, the ${ }^{\circ}$ Brix of OD and OD+PG decreased significantly $(\mathrm{p}<0.05)$ from day 18 of storage, while the ${ }^{\circ}$ Brix of the $\mathrm{OD}+\mathrm{PG}+\mathrm{L}$ sample did not change significantly. The decrease of ${ }^{\circ} \mathrm{Brix}$ in the indicated samples could have been due to the action of microorganisms.

The consistency of the jams stored at room temperature (Figure 2) decreased at the end of the 24-day storage (increased advance distance). OD lost consistency from the $10^{\text {th }}$ day, while $\mathrm{OD}+\mathrm{PG}$ and $\mathrm{OD}+\mathrm{PG}+\mathrm{L}$ showed a significant decrease $(\mathrm{p}<0.05)$ from day 18 , probably due to attack by microorganisms. 
On applying a PCA analysis (Figure 3) to the average values of the colour coordinates $\mathrm{L}^{*}, \mathrm{a}^{*}$ and $\mathrm{b}^{*}, \mathrm{~h}_{\mathrm{ab}}{ }^{*}$ and $\mathrm{C}_{\mathrm{ab}}{ }^{*}$ of the jams during storage, the first two components showed eigenvalues higher than 1 . The consideration of both components accounted for $90.38 \%$ of the total variability. The first component (C1), explaining $66.78 \%$ of the variability, was associated with $\mathrm{h}_{\mathrm{ab}} *(\mathrm{r}=0.99), \mathrm{a}^{*}(\mathrm{r}=0.96), \mathrm{C}_{\mathrm{ab}} *(\mathrm{r}=0.89)$ and $\mathrm{b}^{*}$ $(\mathrm{r}=0.78)$ values. The second component $(\mathrm{C} 2)$ accounted for $23.60 \%$ of the variability and was mainly associated with the $\mathrm{L}^{*}(\mathrm{r}=0.91)$ value. At the beginning of the storage period, strawberry jams were placed in the PCA plot on the right-hand side as a consequence of their lower $b^{*}$ and $h_{a b} *$ values and higher $a^{*}$ and $C_{a b} *$ values. In this case, $C 2$ separated the $\mathrm{OD}+\mathrm{PG}+\mathrm{L}$ sample from the OD and DO+PG samples. During storage, a decrease of the $\mathrm{C} 1$ component was observed, which meant a decrease in $\mathrm{a}^{*}$ and $\mathrm{C}_{\mathrm{ab}} *$ and an increase of $\mathrm{b}^{*}$ and $\mathrm{h}_{\mathrm{ab}}{ }^{*}$, that is jam become more brown (red color decrease and yellow increase) and color saturation decrease. This fact probably happens as a consequence of enzymatic reactions

L* remained stable throughout the storage period. At the end of storage, the jams were placed on the left-hand side of the PCA plot. Applying a multifactor ANOVA to the $\mathrm{C} 1$ and $\mathrm{C} 2$ values of all the jam samples, there was a significant difference in $\mathrm{C} 1$ with storage time.

In the microbiological study, the development of five kinds of microorganisms was evaluated: aerobic mesophyll, coliforms, lactic acid bacteria (LAB), moulds and yeasts. Coliforms were not present in any of the batches throughout storage. The results of aerobic mesophylls, lactic acid bacteria and moulds and yeast are shown in Figure 4. OD showed higher counts of aerobic mesophylls, LAB, moulds and yeasts until 18 days of storage. The lowest microbial growth was found in $\mathrm{OD}+\mathrm{PG}+\mathrm{L}$, which indicates the antimicrobial effect of the plant extracts studied. The use of pomegranate extract achieved a mean reduction of $0.71,0.52$ and $0.58 \mathrm{log}$ units for aerobic mesophylls LAB, yeasts and moulds, respectively. In the case of $\mathrm{OD}+\mathrm{PG}+\mathrm{L}$, the reductions were $1.52,1.34$ and $1.38 \mathrm{log}$ units. On the other hand, there was a drop in the OD counts from days 10-13, which could be attributed to the exhaustion of nutrients in the product. However, the counts for the three groups of microorganisms tested were always higher for OD jam than OD+PG and OD+PG+L during the first 18 days.

In order to analyze in great detail the evolution of the microbiota present in the three jams during storage, the evolution of aerobic mesophylls, LAB, moulds and yeasts, was modelled according to the Gompertz and Baranyi models (Baranyi \& Roberts, 1994). Table 4 shows the growth parameters obtained from these models. There were no high differences between the two proposed models. The maximum population density $(\mathrm{N})$ was for aerobic mesophylls, around 6.7, 5.9 and $5 \log$ units for $\mathrm{OD}, \mathrm{OD}+\mathrm{PG}$ and $\mathrm{OD}+\mathrm{PG}+\mathrm{L}$, respectively. For LAB, the maximum levels were $6.5(\mathrm{OD}), 6(\mathrm{OD}+\mathrm{PG})$ and $5(\mathrm{OD}+\mathrm{PG}+\mathrm{L}) \log$ units. Finally, in the case of moulds and yeasts, $N$ reached values of $6.8(\mathrm{OD}), 5.8(\mathrm{OD}+\mathrm{PG})$ and $5(\mathrm{OD}+\mathrm{PG}+\mathrm{L})$.

These results confirm the antimicrobial and antifungical capacity of pomegranate and lemon extracts mainly linking to anthocyanins, ellagitannins and other phenolic compounds found in pomegranate (Madrigal-Carballo, Rodriguez, Krueger, Dreher, \& Reed, 2009) and to D-limonene, linalool or citral in lemon extract (Tepe, Akpulat, Sokmen, Daferera, Yumrutas, \& Aydin, 2006; Veldhuizen, Tjeerdsma-Van Bokhoven, Zweijtzer, Burt, \& Haagsman, 2006).

\section{Conclusion}


289

290

291

292

293

294

295

296

297

298

299

300

301

302

303

304

305

306

307

308

309

310

311

312

313

314

315

316

317

318

319

320

321

322

323

324

325

326

327

328

329

330

331

332

333

334

335

In vitro studies show that among plant extracts tested in this study (pomegranate, lemon, rosemary and lemon balsamic) lemon extract presented the highest antifungal activity against the microbiota present in strawberry jam, establishing MIC and MFC at $0.1 \mathrm{~g} / \mathrm{mL}$. Adding extracts increases the stability of this jam during storage at room temperature. The use of plant extracts reduces the microbial charge (aerobic mesophylls, lactic acid bacteria and moulds and yeasts) and is most evident in the case of pomegranate and lemon extracts, which do not cause significant changes in the physicochemical characteristics. Furthermore, adding pomegranate and/or lemon extract improved the consistency of jams during storage. Based on the physicochemical and microbiological parameters obtained in this study, the use of pomegranate and lemon extracts would therefore prolong the shelf-life of strawberry jam made with osmotically dehydrated fruit.

\section{Acknowledgments}

The authors wish to thank the Spanish Ministerio de Educación y Ciencia for the financial support given through Projects AGL 2005-05994. The proof-reading of this paper was funded by the Universidad Politécnica de Valencia, Spain.

\section{References}

AOAC, 2000. Official Methods of Analysis of AOAC International, $17^{\text {th }} \mathrm{ed}$. Gaithersburg, MD, USA.

Baranyi, J., \& Roberts, T.A. (1994). A dynamic approach to predicting bacterial growth in food. International Journal of Food Microbiology, 23, 277-294.

Barry, A.L. (1986). Procedure for testing antimicrobial agents in agar media: theoretical considerations. In V. Lorain, Editor (Esds.), Antibiotics in Laboratory Medicine (2nd ed), Baltimore: Williams \& Wilkins,

Bourne, M. (1982). Food texture and viscosity-concept and measurement. New York: Academic Press.

Davidson, P.M, \& Parish, M.E. (1989). Methods for testing the efficacy of food antimicrobials. Food Tecnology, 1, 148-155.

Ernst, E.J. (2005). Antifungal Agents. Methods and Protocols. , Totowa, New Jersey: Humana Press Inc.

García-Martínez, E., Ruiz-Diaz, G., Martínez-Monzó, J., Camacho, M.M., MartínezNavarrete, N., \& Chiralt, A. (2002). Jam manufacture with osmodehydrated fruit. Food Research Internacional, 35, 301-306.

García-Viguera, C., Zafrilla, P., \& Tomás-Barberán F.A., (1999). Influence of processing and storage conditions in strawberry jam colour. Food Science and technology International. 5, 487-492.

Goessinger, M., Mayer, F., Radocha, N., Hoefler, M., Boner, A., Groll, E., Bauer, R., \& Berghofer, E. (2009). Consumer's color acceptance of strawberry nectars from puree. Journal of Sensory Studies, 24, (1), 78-92

Gómez, F., Igual, M., Camacho, M.M., \& Pagán, M.J. (2012). Effect of the addition of plant extracts on the microbiota of minimally processed strawberry jam and its physicochemical and sensorial properties. CyTA - Journal of Food (In press)

Grigelmo-Miguel, N., \& Martín-Belloso, O, (1999). Influence of fruit dietary fibre addition on physical and sensorial properties of strawberry jams. Journal of Food Engineering. $41,13-21$. 
Herrmann, K. (1972). Anthocyanins in Food. Zeitschrift für Lebens-mittel-Untersuchung und Forschung, 148, 290-302.

Igual, M., Castelló, M. L., Ortolá, M. D., \& Andres, A. (2008). Influence of vacuum impregnation on respiration rate, mechanical and optical properties of cut persimmon. Journal of Food Engineering. 86, (3), 315-323.

Igual, M., Contreras, C., \& Martínez-Navarrete, N. (2010). Non-conventional techniques to obtain grapefruit jam. Innovative Food Science and Emerging Technologies, 1(2), 335345 .

ISO 21527-1:2008 RSSMicrobiology of food and animal feeding stuffs -- Horizontal method for the enumeration of yeasts and moulds -- Part 1: Colony count technique in products with water activity greater than 0,95 ISO 4832:2006 RSSMicrobiology of food and animal feeding stuffs -- Horizontal method for the enumeration of coliforms - Colony-count technique ISO 15214:1998 RSSMicrobiology of food and animal feeding stuffs -- Horizontal method for the enumeration of mesophilic lactic acid bacteria -- Colony-count technique at 30 degrees $\mathrm{C}$

ISO 4833:2003 RSSMicrobiology of food and animal feeding stuffs -- Horizontal method for the enumeration of microorganisms -- Colony-count technique at 30 degrees $\mathrm{C} \mathrm{Jia,}$ H. L., Ji, Q. L., Xing, S. L., Zhang, P. H., Zhu, G. L., \& Wang, X. H. (2010). Chemical Composition and Antioxidant, Antimicrobial Activities of the Essential Oils of Thymus marschallianus Will. and Thymus proximus Serg. Journal of Food Science. 75, (1), E59-E65.

Krishnamurthy, Y. L., \& Shashikala, J. (2006). Inhibition of aflatoxin B1 production of Aspergillus flavus, isolated from soybean seeds by certain natural plant products. Letters in Applied Microbiology, 43, (5), 469-474.

Madrigal-Carballo, S., Rodriguez, G., Krueger, C. G., Dreher, M., \& Reed, J. D. (2009). Pomegranate (Punica granatum) supplements: authenticity, antioxidant and polyphenol composition. Journal of Functional Foods, 1, (3), 324-329.

Pascual, M.R., \& Calderón, V. (2000). Microbiología Alimentaria. Metodología Analítica para Alimentos y Bebidas. $2^{a}$ Edición. Madrid, España.: Díaz de Santos S.A., PerezFons, L., Garzon, M. T., \& Micol, V. (2010). Relationship between the antioxidant capacity and effect of rosemary (Rosmarinus officinalis L.) polyphenols on membrane phospholipid order. Journal of Agricultural \& Food Chemistr,. 58, (1), 161-171.

Ponce, A. G.; Fritz, R.; Valle, C., \& Del, Roura, S. I. (2003). Antimicrobial activity of essential oils on the native microflora of organic Swiss chard. LebensmittelWissenschaft und-Technologie, 36, (7), 679-684.

Redalen, G., \& Haffner, K. (2002). Quality of raspberry jam individual cultivars after one year of storage. Acta Horticulturae, 585, 525-530.

Shi, X. Q., Chiralt, A., Fito, P., Serra, J., Escoin, C., \& Gasque, L. (1996). Application of osmotic dehydration technology on jam processing. Drying Technology, 14(3\&4), 841-857.

Sundfø̈r Wegner, M. (2001). Evaluation of strawberry cultivars for jam with focus on colour characteristics (Master dissertation Thesis). Agricultural University of Norway, Aas.

Tepe, B., Akpulat, H.A., Sokmen, M., Daferera, D., Yumrutas, O., \& Aydin, E. (2006). Screening of the antioxidative and antimicrobial properties of the essential oils of 
382

383

384

385

386

387

388

389

390

391

392

393

394

395

396

397

398

399

400

401

402

403

404

405

Pimpinella anisetum and Pimpinella flabellifolia from Turkey, Food Chemistry, 97 (4), 719-724.

Veldhuizen, E.J., Tjeerdsma-Van Bokhoven, J.L., Zweijtzer, C., Burt,S.A., \& Haagsman, H.P. (2006). Structural requirements for the antimicrobial activity of carvacrol, Journal of Agricultural and Food Chemistry, 54, 1874-1879.

Viguera, C. G., Zafrilla, P., \& Barberan, E.T. (1997). Determination of authenticity of fruit jams by HPLC análisis of anthocyanins. Journal of Science and Food Agriculture, 73, 207-213.

Viuda-martos, M., Ruiz-Navajas, Y., Fernandez-Lopez, J., \& Perez-Alvarez, J. (2008). Antifungal activity of lemon (Citrus lemon L.), mandarin (Citrus reticulata L.), grapefruit (Citrus paradisi L.) and orange (Citrus sinensis L.) essential oils. Food Control, 19, (12), 1130-1138.

Voravuthikunchai, S., Lortheeranuwat, A., \& Jeeju, W. (2004). Effective medicinal plants against enterohaemorrhagic Escherichia coli O157:H7. Journal of Ethnopharmacology, 94, 49-54.

Withy, L. M., Nguyen, T.T., Wrolstad, R.E., \& Heatherbell, D.A. (1993). Storage changes in anthocyanin content of red raspberry juice concentrate. Journal of Food Science, 58, 190-192.

Xu, G., D. Liu, J. Chen, X. Ye, Y. Ma, \& Shi, J. (2008). Juice components and antioxidant capacity of citrus varieties cultivated in China. Food Chemistry, 106, 545-551.

Yesil-Celiktas, O., Sevimli, C., Bedir, E., \& Vardar-Sukan, F. (2010). Inhibitory effects of rosemary extracts, carnosic acid and rosmarinic acid on the growth of various human cancer cell lines. Plant Foods for Human Nutrition, 65(2), 158-163. 


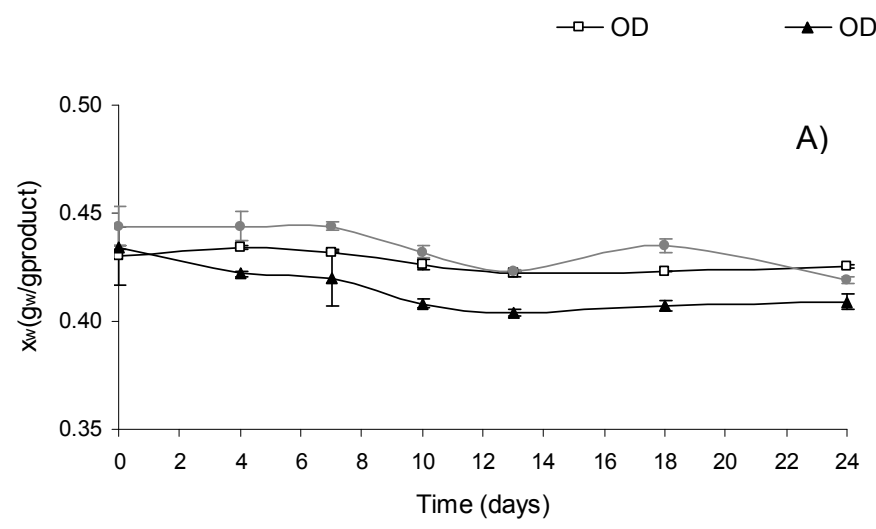

$\rightarrow O D+P G+L$
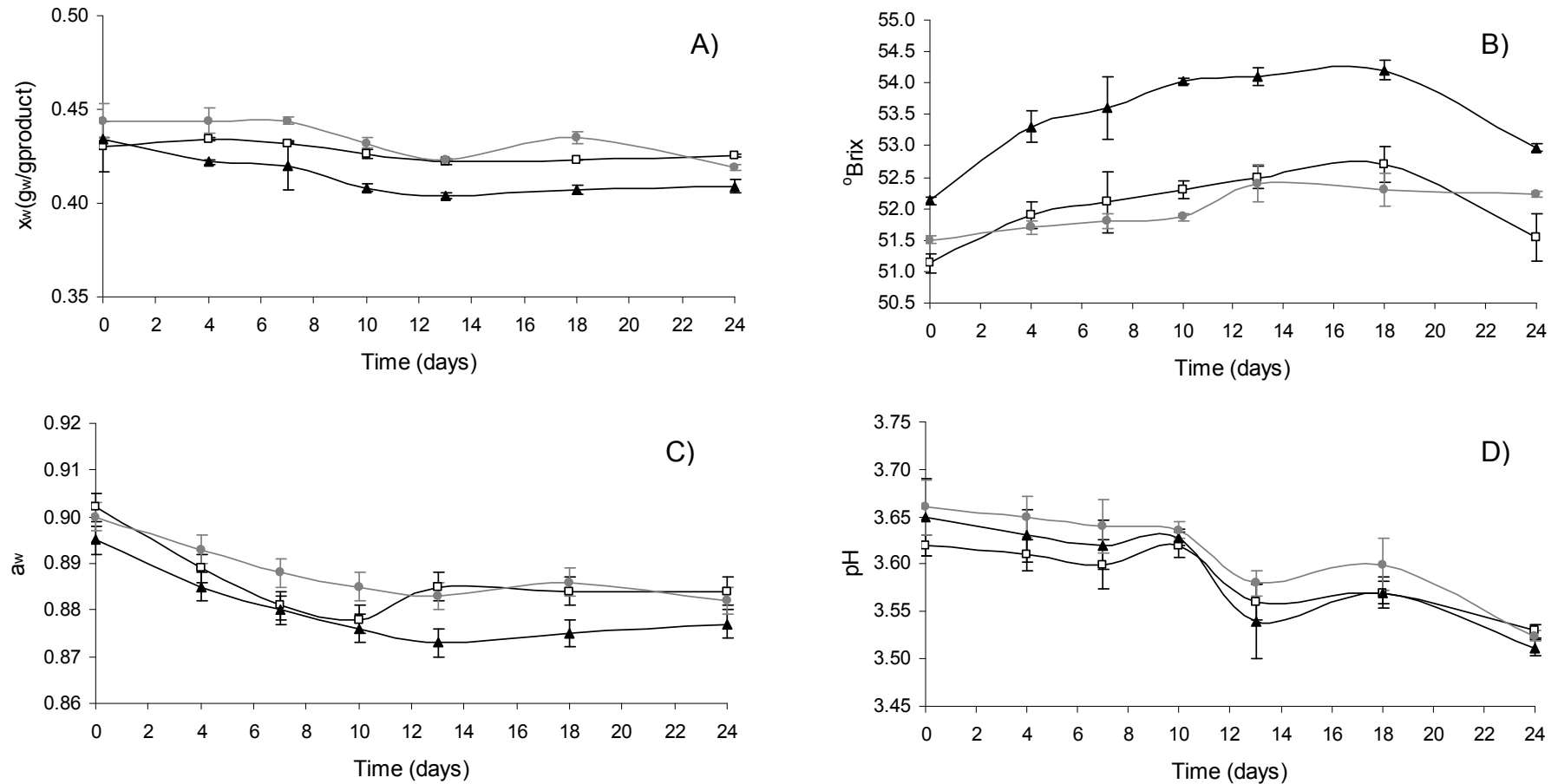

Figure 1. Evolution of $A$ ) moisture content $\left.\left(x_{w}\right), B\right)^{\circ}$ Brix,$\left.C\right)$ water activity $\left.\left(a_{w}\right), D\right) p H$ of formulated jams throughout storage $\left(24\right.$ days at $\left.25^{\circ} \mathrm{C}\right)$.

Figura 1. Evolución de $A)$ contenido de humedad $\left.\left(x_{w}\right), B\right){ }^{\circ}$ Brix , C) actividad del agua $\left.\left(a_{w}\right), D\right) ~ p H$ de las mermeladas estudiadas durante el almacenamiento (24 días a $\left.25^{\circ} \mathrm{C}\right)$. 

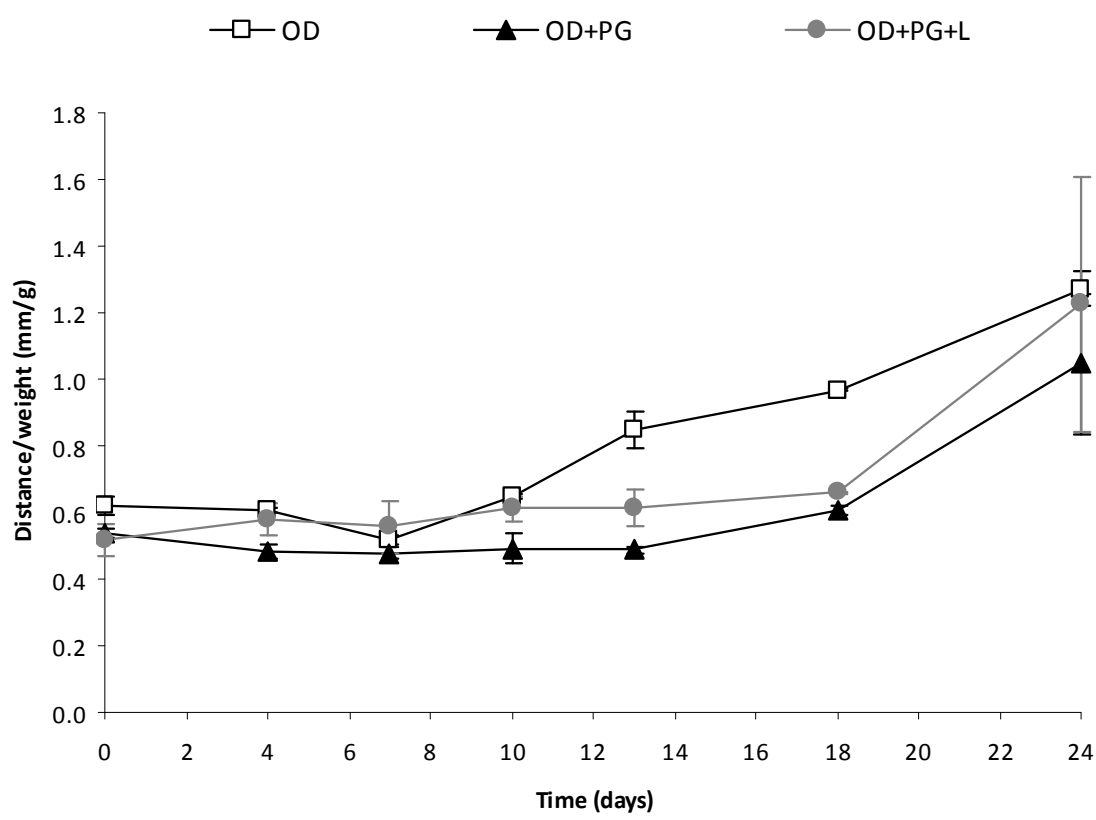

Figure 2. Evolution of consistency (flow distance corrected for the sample weight) of formulated jams throughout storage ( 24 days at $\left.25^{\circ} \mathrm{C}\right)$.

Figura 2. Evolución de la consistencia (distancia del flujo corregido por el peso de muestra) de las mermeladas formuladas durante el almacenamiento (24 días a $25^{\circ} \mathrm{C}$ ). 
Figure 3. Principal Component Analysis (PCA) of the values of colour parameters of all the jams.

Figura 3. Análisis de Componentes Principales (PCA) de los valores de los parámetros de color de todas las mermeladas. 
- OD

$\square \mathrm{OD}+\mathrm{PG} \quad \square \mathrm{OD}+\mathrm{PG}+\mathrm{L}$
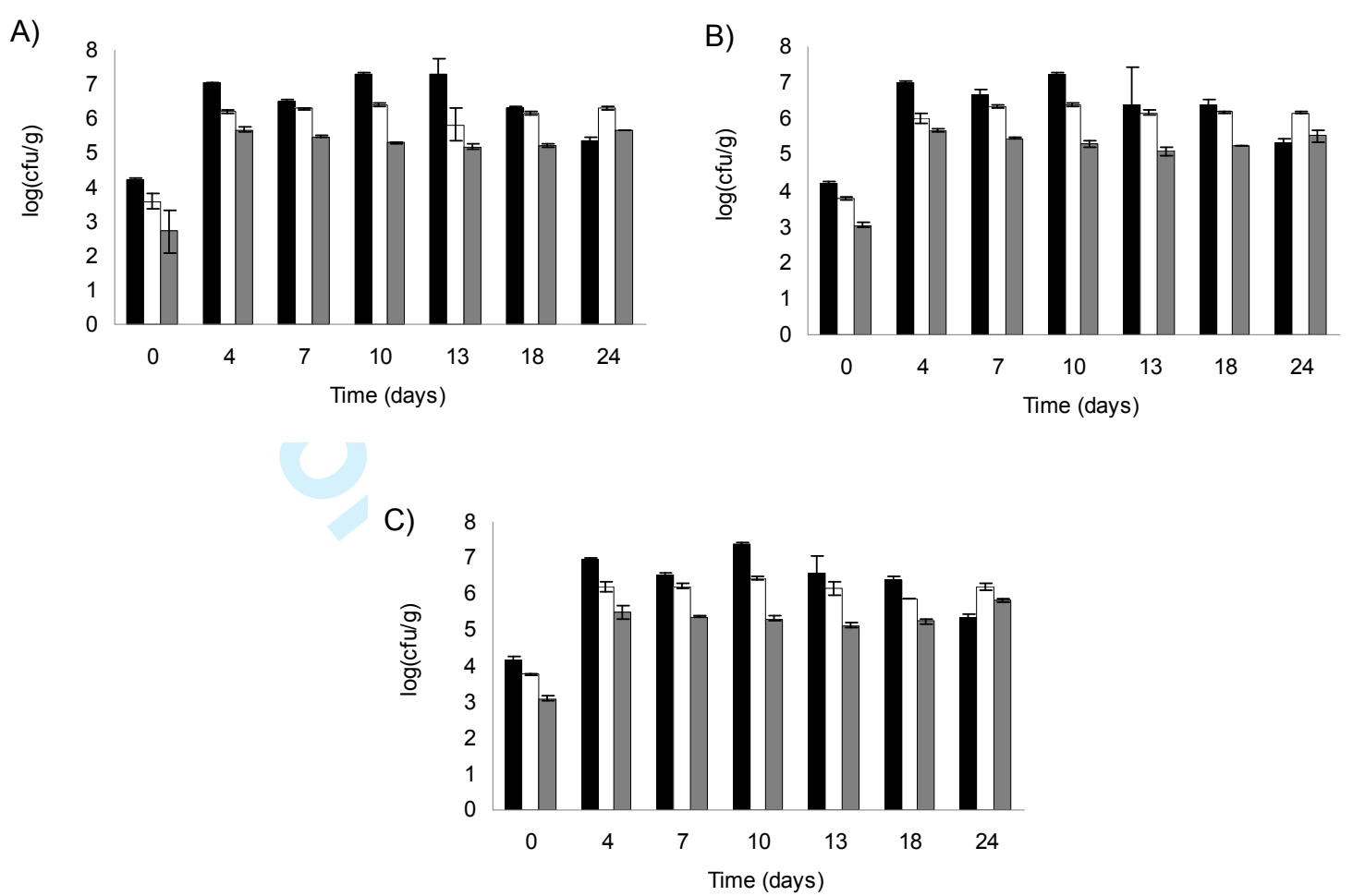

Figure 4. Evolution of A) aerobic mesophylls, B) lactic acid bacteria (LAB) and C) moulds and yeasts of formulated jams throughout storage (24 days at $25^{\circ} \mathrm{C}$ ).

Figura 4. Evolución of $A$ ) mesófilos aerobicos, B) bacterias ácido lácticas (LAB) and C) hongos y levaduras de las mermeladas formuladas durante el almacenamiento (24 días a $25^{\circ} \mathrm{C}$ ). 
Table 1. Mean values (and standard deviation) of ${ }^{\circ}$ Brix, $\mathrm{pH}$, water activity $\left(\mathrm{a}_{\mathrm{w}}\right)$, moisture content $\left(\mathrm{X}_{\mathrm{w}}\right)$ and the values of flow distance corrected for the sample weight of formulated jams.

Tabla 1. Valores medios (y desviación estándar) de ${ }^{\circ} \mathrm{Brix}, \mathrm{pH}$, actividad del agua $\left(\mathrm{a}_{\mathrm{w}}\right)$, contenido en humedad $\left(x_{w}\right)$ distancia del flujo por peso de muestra de las mermeladas formuladas.

\begin{tabular}{cccc}
\hline SAMPLE & OD & OD +PG & OD+PG+L \\
\hline${ }^{\circ}$ Brix & $51.1(0.1)^{\mathrm{c}}$ & $52.1(0.1)^{\mathrm{a}}$ & $51.5(0.1)^{\mathrm{b}}$ \\
$\mathbf{a}_{\mathbf{w}}$ & $0.903(0.003)^{\mathrm{a}}$ & $0.895(0.003)^{\mathrm{b}}$ & $0.901(0.003)^{\mathrm{a}}$ \\
$\mathbf{x}_{\mathbf{w}}$ & $0.435(0.009)^{\mathrm{a}}$ & $0.4341(0.0008)^{\mathrm{a}}$ & $0.444(0.009)^{\mathrm{a}}$ \\
$\mathbf{p H}$ & $3.63(0.01)^{\mathrm{a}}$ & $3.65(0.01)^{\mathrm{a}}$ & $3.66(0.01)^{\mathrm{a}}$ \\
Distance/weight (mm/g) & $0.62(0.03)^{\mathrm{a}}$ & $0.538(0.016)^{\mathrm{ab}}$ & $0.52(0.05)^{\mathrm{b}}$ \\
\hline
\end{tabular}

The same letter in superscript within columns indicates homogeneous groups established by ANOVA $(p<0.05)$ 
Table 2. Mean values (and standard deviation) of colour parameters of formulated jams.

Tabla 2. Valores medios (y desviación estándar) de los parámetros de color de las mermeladas formuladas.

\begin{tabular}{cccc}
\hline Sample & OD & OD+PG & OD+PG+L \\
\hline $\mathbf{L}^{*}$ & $26.3(1.1)^{\mathrm{a}}$ & $24.9(0.2)^{\mathrm{ab}}$ & $23.9(1.2)^{\mathrm{b}}$ \\
$\mathbf{a}^{*}$ & $28.7(0.6)^{\mathrm{a}}$ & $28.0(0.3)^{\mathrm{a}}$ & $28.0(1.4)^{\mathrm{a}}$ \\
$\mathbf{b}^{*}$ & $13.3(0.6)^{\mathrm{a}}$ & $12.3(0.1)^{\mathrm{a}}$ & $12.8(1.1)^{\mathrm{a}}$ \\
$\mathbf{C}^{*}{ }^{\mathrm{ab}}$ & $31.6(0.8)^{\mathrm{a}}$ & $30.6(0.3)^{\mathrm{a}}$ & $30.7(1.8)^{\mathrm{a}}$ \\
$\mathbf{h}^{*}{ }^{\mathrm{ab}}$ & $24.9(0.5)^{\mathrm{a}}$ & $23.7(1.0)^{\mathrm{b}}$ & $24.5(0.8)^{\mathrm{ab}}$ \\
$\Delta \mathbf{E}$ & -- & $2.1(0.7)^{\mathrm{a}}$ & $3.1(0.2)^{\mathrm{b}}$
\end{tabular}

The same letter in superscript within columns indicates homogeneous groups established by ANOVA $(p<0.05)$ 
Table 3. Mean values (and standard deviation) of microbial characterization of formulated jams

Tabla 3 Valores medios (y desviación estándar) de los parámetros obtenidos de la caracterización de las mermeladas formuladas

\begin{tabular}{ccccc}
\hline Sample & Aerobic mesophylls & Lactic acid bacterias & Moulds and yeasts & Coliforms \\
\hline OD & $1.67^{\star} 10^{4}\left(2.67^{\star} 10^{3}\right)^{\mathrm{a}}$ & $1.60^{\star} 10^{4}\left(1.47^{\star} 10^{3}\right)^{\mathrm{a}}$ & $1.55^{\star} 10^{4}\left(2.10^{\star} 10^{3}\right)^{\mathrm{a}}$ & 0 \\
OD+PG & $4.20^{*} 10^{3}\left(2.12^{*} 10^{3}\right)^{\mathrm{b}}$ & $6.05^{\star} 10^{3}\left(4.95^{\star} 10^{2}\right)^{\mathrm{b}}$ & $5.85^{\star} 10^{3}\left(4.95^{\star} 10^{2}\right)^{\mathrm{b}}$ & 0 \\
OD+PG+L & $8.37^{*} 10^{2}\left(7.03^{*} 10^{2}\right)^{\mathrm{b}}$ & $1.10^{*} 10^{3}\left(1.72^{*} 10^{2}\right)^{\mathrm{C}}$ & $1.25^{\star} 10^{3}\left(2.28^{\star} 10^{2}\right)^{\mathrm{b}}$ & 0 \\
\hline
\end{tabular}

The same letter in superscript within columns indicates homogeneous groups established by ANOVA $(p<0.05)$ 
Table 4. Maximum density population (N) for microbiota present in the three batches of strawberry jam.

Tabla 4. Máxima densidad de población $(\mathrm{N})$ de la microbiota presente en los tres lotes de mermelada de fresa.

\begin{tabular}{cccccc}
\hline Microorganisms & Parameter & Models & OD & OD+PG & OD+PG+L \\
\hline Aerobic mesophylls & $\mathrm{N}(\log \mathrm{cfu} / \mathrm{mL})$ & Gompertz & 6.667 & 5.917 & 5.000 \\
& & Barany & 6.667 & 5.917 & 5.000 \\
LAB & $\mathrm{N}(\log \mathrm{cfu} / \mathrm{mL})$ & Gompertz & 6.503 & 6.000 & 5.000 \\
& & Barany & 6.500 & 6.000 & 5.000 \\
Moulds and yeasts & $\mathrm{N}(\log \mathrm{cfu} / \mathrm{mL})$ & Gompertz & 6.757 & 5.833 & 5.000 \\
& & Barany & - & 5.833 & 5.000 \\
\hline
\end{tabular}

URL: http://mc.manuscriptcentral.com/tcyt 